\title{
CHOICE OF CATTLE MANURE REMOVAL SYSTEM DEPENDING ON MANURE PHYSICAL PROPERTIES
}

\author{
Alexander Briukhanov, Ekaterina Shalavina, Pavel Gridnev, Tatyana Gridneva \\ Federal Scientific Agroengineering Centre VIM, Russia \\ shalavinaev@mail.ru
}

\begin{abstract}
Cattle manure is a mixture of solid and liquid animal excrement, bedding material, process water and feed residues. Essentially, this is a polydisperse suspension, the density and viscosity of which depend on the manure composition and the time it stays in the livestock house. Animal excrement is the most unstable manure component; its composition varies with animal diets and productivity. The study aim was to identify the optimal technical device for removing manure from the livestock house with due account for the physical properties of cattle excrement/manure. At the first stage, the mass of manure produced and its moisture content were calculated by the mass balance method, taking into account the diets, animal productivity, and the mass of moisture-absorbing material and process water, which gets into manure in the animal house. At the second stage, the optimal technical device for manure removal was identified, its parameters and technical and economic indicators were determined. Calculations were made for a cattle complex with the total stock of 1249 heads with the loose housing of animals on sawdust bedding. The estimated daily output of manure was $56 \mathrm{t}$ with the integral moisture content of $90 \%$. After the review of different manure removal systems, the hydraulic scraper unit, with the scraper moving in steps, was found optimal for the calculated manure properties. It ensured $98 \%$ or above manure removal, the specific energy requirement of manure transportation within $0.3-0.5 \mathrm{kWh} \cdot \mathrm{t}^{-1}$, and error-free life of at least 700 hours. Under the manure canal width of $3400 \mathrm{~mm}$, depth of $200 \mathrm{~mm}$ and length of $75000 \mathrm{~mm}$, the scraper height of $180 \mathrm{~mm}$, and the moving speed of $4.3 \mathrm{~m} \cdot \mathrm{min}^{-1}$, the power consumption of one scraper ranged from 1.28 to $1.52 \mathrm{~kW}$. Under the given moisture content of the manure removed and the cleaning interval of 4 hours, the maximum length of manure heap transferred in the canal for a distance of 50-60 m was $3.4 \mathrm{~m}$. The average productivity of the scraper unit was $4.3 \mathrm{t} \cdot \mathrm{h}^{-1}$.
\end{abstract}

Key words: manure, balance method, manure removal, scraper.

\section{Introduction}

In the Russian Federation, the manure output is calculated by the mass of animal excrement (faeces and urine). The excrement mass, humidity and NPK content values for each animal category are specified in the relevant guidance documents, which also define the age and gender groups of animals [1-4]. These regulatory data are used when designing new cattle complexes.

Over the past 10 years, a database on the nutrient content in cattle excrement has been maintained at IEEP-branch of FSAC VIM. The data are taken from the laboratory analysis protocols of the research laboratory of analytical methods of environmental engineering of the institute as a part of research and cooperation with enterprises in the North-West Federal District.

Comparison of regulatory data on quantitative and qualitative characteristics of cattle excrement with the average factual data from the database showed the difference to be up to $40 \%$ [5]. Therefore, the calculation method of these characteristics needs an upgrade.

The mass balance method is used to calculate the quantity and quality properties of excrements in Finland, Estonia, Latvia, Poland and Sweden [6]. Comparison of the calculated and actual data proves the accuracy of the mass balance method [7].

In an animal house the excrements mix with bedding and process water resulting in manure. The technology of manure removal from the livestock house and the applied equipment are selected with regard to the characteristics of the manure produced.

The study aim was to identify the optimal technical device for removing manure from the livestock house with due account for the physicals properties of cattle excrement/manure.

\section{Materials and methods}

The study was divided into two stages. At the first stage, the mass of manure produced and its moisture content were calculated by the mass balance method, taking into account the diets, animal productivity, and the mass of moisture-absorbing material and process water, which gets into manure in the animal house [8-13].

The excrement mass per one animal was determined by the formula: 


$$
M_{E}=M_{F}+M_{U},
$$

where $M_{E}$ - excrement mass per one animal, $\mathrm{kg} \cdot \mathrm{day}^{-1}$;

$M_{F}$ - faeces mass per one animal, $\mathrm{kg} \cdot \mathrm{day}^{-1}$;

$M_{U}$ - urine mass per one animal, $\mathrm{kg} \cdot \mathrm{day}^{-1}$.

The faeces mass per one animal was determined by the formula:

$$
M_{F}=\left(M_{R 1}-M_{R 2}\right) \cdot \frac{100}{100-M C_{F}},
$$

where $M_{R 1}-$ mass of feed dry matter received within the diet per one animal, $\mathrm{kg} \cdot \mathrm{day}^{-1}$;

$M_{R 2}$ - mass of digested feed dry matter received within the diet per one animal, $\mathrm{kg} \cdot \mathrm{day}^{-1}$;

$M C_{F}$ - faeces moisture content, $\%$.

The urine mass per one animal was determined by the formula:

$$
M_{U}=\frac{M_{F}}{K},
$$

where $K$ - conversion factor of the faeces mass into the urine mass, dimensionless. This factor is generally calculated for each animal category in accordance with management [1].

Moisture content of animal excrement is calculated by the formula:

$$
M C_{E}=\frac{M C_{F} \cdot M_{F}+\frac{M_{F}}{K} \cdot M C_{U}}{M_{E}},
$$

where $M C_{E}-$ moisture content of animal excrement, \%;

$M C_{U}$ - moisture content of animal urine, $\%$.

In an animal house, the excrements mix with the bedding and process water producing manure. The total mass of manure is calculated by the formula:

$$
M_{\text {Manure }}=\sum_{j=1}^{m}\left(M_{E}+M_{W}+M_{B}\right) \cdot n j,
$$

where $M_{\text {Manure }}-$ manure mass per animal, $\mathrm{kg} \cdot \mathrm{day}^{-1}$;

$M_{E}$ - daily output of excrements (faeces and urine), $\mathrm{kg} \cdot \mathrm{day}^{-1}$;

$M_{W}$ - daily process water consumption, $\mathrm{kg} \cdot \mathrm{head}^{-1} \cdot \mathrm{day}^{-1}$;

$M_{B}$ - daily bedding consumption, $\mathrm{kg} \cdot \mathrm{day}^{-1}$;

$n j-$ number of animals in each category;

$m$ - number of animal categories.

In the Russian regulatory documents the rates of process water consumption are set in $1 \cdot$ head $^{-1} \cdot$ day $^{-1}$ but in our calculations we used $\mathrm{kg} \cdot \mathrm{head}^{-1} \cdot \mathrm{day}^{-1}$ as the value of water density was 1 .

The moisture content of manure per one animal was determined by the formula:

$$
M C_{\text {Manure }}=\frac{M C_{E} \cdot M_{E}+100 \cdot M_{W}+M C_{B} \cdot M_{B}}{M_{\text {Manure }}},
$$

where $M C_{\text {Manure }}-$ moisture content per one animal, \%;

$M C_{B}$ - moisture content of bedding, $\%$.

At the second stage, in order to select the optimal manure removal system and to justify this choice, various possible technological and technical solutions, both for tied stable and loose housing, were analysed. For the optimization criterion we used the minimal total costs of removing one ton of manure with specific physical properties. It was established that the optimal technical device for manure removal was a push-rod manure remover with the hydraulic drive in case of the tied stable 
housing and a hydraulic scraper unit with the scraper moving in steps in case of the loose housing [14].

The optimal technical device for manure removal from the animal house was identified with the use of the below dependences.

Correlation between the manure transportation zone and the filling degree of the manure channel is expressed as follows:

$$
\left\{\begin{array}{l}
L_{T R}=2.93 \cdot \Delta+2227 \\
L_{\text {Fill }}=-3.28 \cdot \Delta+638 \\
L_{O}=-1.7 \cdot \Delta+451
\end{array},\right.
$$

where $L_{T R}, L_{F i l l}, L_{O}$ - zones of active manure transportation, closing and opening of the scrapers, correspondingly, $\mathrm{mm}$;

$\Delta$ - filling degree of manure channel, unit fraction.

The correlation between of the dragged manure heap length and the spacing of scrapers is expressed as follows:

$$
\left\{\begin{array}{l}
L_{1}=0.0113 \cdot \Delta+1.0667 \\
L_{2}=0.0043 \cdot \Delta+1.0933 \\
L_{3}=0.0027 \cdot \Delta+1.0333
\end{array}\right.
$$

where $L_{1}, L_{2}, L_{3}$ - lengths of the dragged manure heap under the spacing of scrapers of $0.5,1.0$ and $1.5 \mathrm{~m}$, correspondingly, $\mathrm{m}$.

The following correlations were established for calculating the performance of a push-rod manure remover depending on the spacing of scrapers and the filling degree of the manure channel:

$$
\left\{\begin{array}{l}
C_{1}=-0.104 \cdot \Delta^{2}+92.708 \cdot \Delta-851.5 \\
C_{2}=-0.558 \cdot \Delta^{2}+142.82 \cdot \Delta-1899.3 \\
C_{3}=-0.064 \cdot \Delta^{2}+69.28 \cdot \Delta-546
\end{array}\right.
$$

where $C_{1}, C_{2}, C_{3}$ - performance of the device under investigation under the spacing of scrapers of $0.5,1.0$ and $1.5 \mathrm{~m}$, correspondingly, $\mathrm{kg} \cdot \mathrm{h}^{-1}$.

A scraper manure removal unit was also considered, with the scrapers moving in steps, the hydraulic drive of the traction tool in the form of a steel band and the automatic reversal of the scraper at the extreme points of the channel. One hydraulic station can drive up to four traction tools. The scraper unit is controlled automatically according to the preset sequence. The performance of the scraper unit is calculated similarly to that of a push-rod manure remover.

\section{Results and discussion}

The current trends in the development of animal husbandry in Russia are larger farms and bigger animal stock on one site. As of the end of 2017, in Leningrad Region over $60 \%$ of livestock farms have over 800 heads of animal stock (Fig. 1). The minimum number of animals on the complexes is 207 heads.

A cattle complex with the total animal stock of 1249 heads, located in Gatchina District of Leningrad Region, with loose housing on sawdust with zero grazing, was selected as a pilot enterprise in the study. The complex specialises in milk production and cattle breeding.

The calculation results of quantitative and qualitative characteristics of animal excrement are shown in Table 1. The calculated data were compared with the data specified in the manure management guidelines, (Fig. 2). 


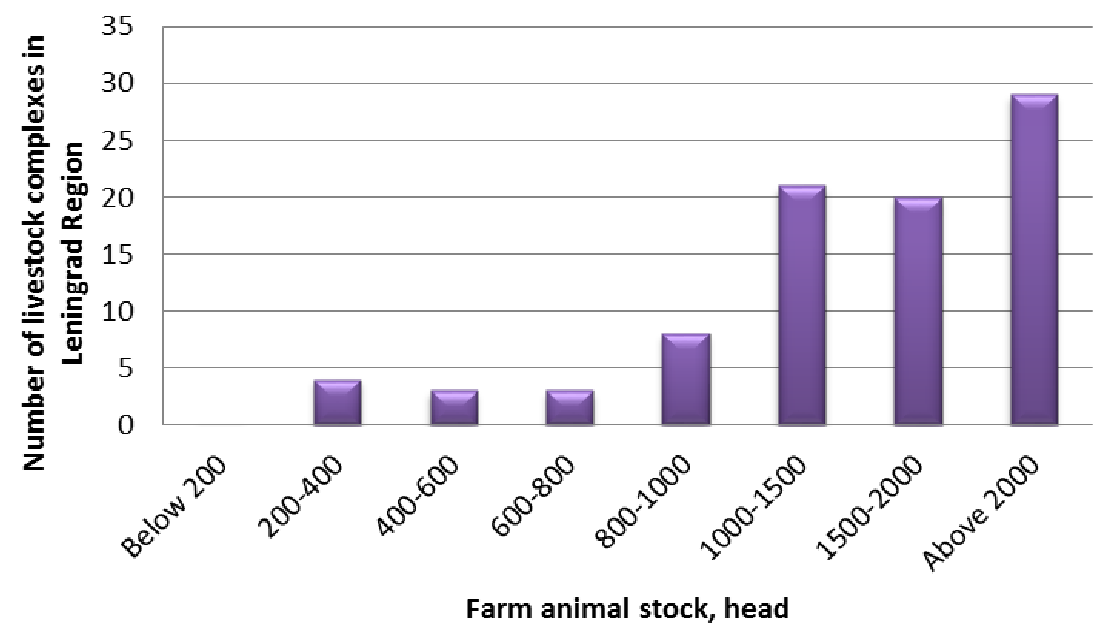

Fig. 1 Distribution of cattle by farm capacity in Leningrad Region

Calculated characteristics of cattle excrement

Table 1

\begin{tabular}{|l|c|c|}
\hline \multicolumn{1}{|c|}{ Indicator } & Value & Unit \\
\hline Excrement mass per cow - early lactation & 69.6 & $\mathrm{~kg}$ per cow per day \\
\hline Excrement mass per cow - mid lactation & 62.5 & $\mathrm{~kg}$ per cow per day \\
\hline Excrement mass per cow - late lactation & 61 & $\mathrm{~kg}$ per cow per day \\
\hline Excrement mass per cow - dry period & 40.7 & $\mathrm{~kg}$ per cow per day \\
\hline $\begin{array}{l}\text { Average excrement mass per cow (for all four lactation } \\
\text { periods) }\end{array}$ & 60 & $\mathrm{~kg}$ per cow per day \\
\hline $\begin{array}{l}\text { Average moisture content of excrement per cow (for all } \\
\text { four lactation periods) }\end{array}$ & 88.4 & $\%$ \\
\hline Excrement mass per 1 animal - calf (age 0-6 months) & 5.7 & $\mathrm{~kg}$ per animal per day \\
\hline Excrement moisture content - calf (age 0-6 months) & 85.5 & $\mathrm{~kg}$ per animal per day \\
\hline $\begin{array}{l}\text { Excrement mass per 1 animal - heifer (age 6 months to } \\
\text { calving) }\end{array}$ & 28.1 & $\%$ \\
\hline $\begin{array}{l}\text { Excrement moisture content - heifer (age 6 months to } \\
\text { calving) }\end{array}$ & 87.7 & \multicolumn{1}{|c|}{$\%$} \\
\hline
\end{tabular}

The comparison showed that the calculated excrement mass per cow exceeded the standard one by $9 \%$; the calculated excrement mass per calf (age 0-6 months) exceeded the standard by $21 \%$; calculated excrement mass per heifer (age 6 months to calving) exceeded the standard by $50 \%$. The calculated and standard values animal excrement moisture content differed by no more than $3 \%$.

To identify the optimal manure removal device, an important indicator is the excrement mass. Therefore, the calculated values of the excrement mass were taken to calculate the mass of manure, under which the continuous operation of the device is provided (Table 2).

As a result of calculations for the selected cattle complex, the daily output of manure with the integral moisture content of $90 \%$ was found to be 56 tons.

After the review of previously investigated different manure removal systems the hydraulic scraper unit, with the scraper moving in steps, was found optimal to handle cattle manure with the obtained quantitative and qualitative characteristics. According to previous investigations [13;14], in a cow barn with the sawdust bedding introduced at the rate of 1 to $3 \mathrm{~kg}$ per head per day, with the manure channel $3400 \mathrm{~mm}$ wide, $200 \mathrm{~mm}$ deep and $75 \mathrm{~m}$ long, with the scraper height of $180 \mathrm{~mm}$ and the moving speed of $4.3 \mathrm{~m} \cdot \mathrm{min}^{-1}$, the unit ensured $98 \%$-plus manure removal, specific energy requirement of manure transportation within $0.3-0.5 \mathrm{kWh} \cdot \mathrm{t}^{-1}$, and error-free life of at least 700 hours; the power consumption of one scraper ranged from 1.28 to $1.52 \mathrm{~kW}$. 


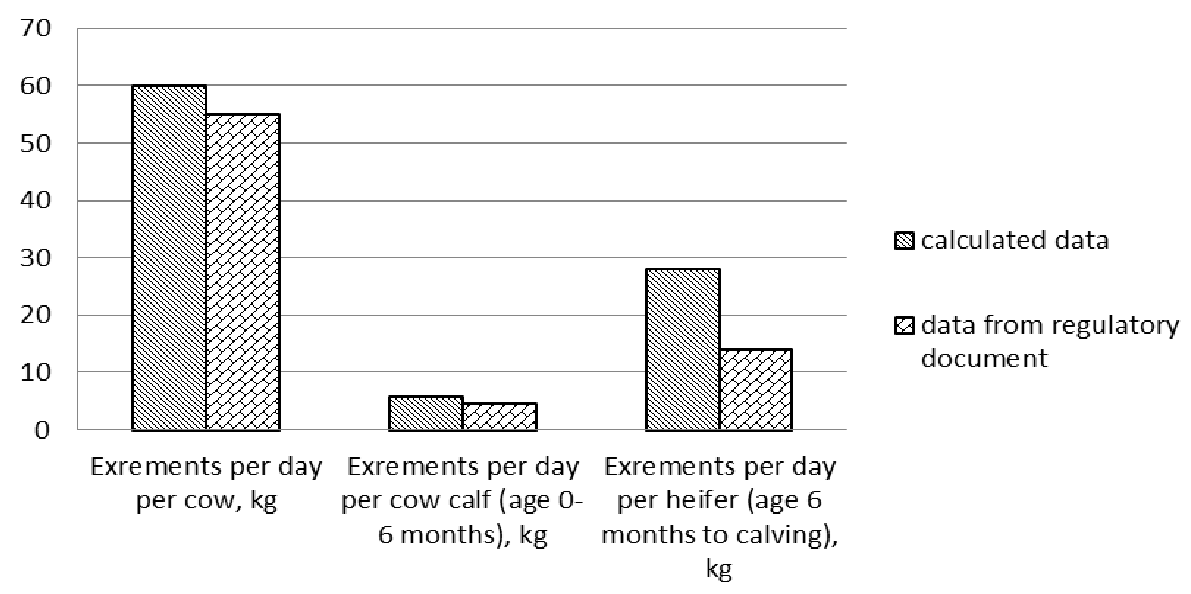

Fig. 2. Comparison of calculated and regulatory data in terms of excrement mass

Under the given moisture content of the manure removed and the cleaning interval of 4 hours, the maximum length of the manure heap transferred in the canal for a distance of 50-60 m was $3.4 \mathrm{~m}$. The average productivity of the scraper unit was $4.3 \mathrm{t} \cdot \mathrm{h}^{-1}$.

Table 2

Calculated characteristics of cattle manure

\begin{tabular}{|l|c|c|}
\hline \multicolumn{1}{|c|}{ Indicator } & Value & Unit \\
\hline Manure mass per 1 cow & 103 & kg per cow per day \\
\hline Manure mass per 1 calf (age 0-6 months) & 14.7 & kg per animal per day \\
\hline Manure mass per 1 heifer (age 6 months to calving) & 38.1 & kg per animal per day \\
\hline Moisture content of cow manure & 91.2 & $\%$ \\
\hline Moisture content of calf manure (age 0-6 months) & 84.8 & $\%$ \\
\hline Moisture content of heifer manure (age 6 months to calving) & 87.2 & $\%$ \\
\hline
\end{tabular}

\section{Conclusions}

Intensification of the livestock industry, cattle farming in particular, leads to an increase in the number of animals located on particular sites resulting in significant rise in manure volumes. In Leningrad Region, over $60 \%$ of cattle-breeding complexes have an animal stock over 800 heads, with each complex producing above 70 tons of manure per day.

Quantitative and qualitative characteristics of cattle manure were calculated based on the daily mass of excrement, bedding material and process water by the mass balance method with due account for the used diets for each animal category. By the calculation results for the cattle complex with the loose housing of 1249 animals on the bedding, 56 tons of manure are produced daily with the integral moisture content of $90 \%$.

The hydraulic scraper unit, with the scraper moving in steps, was found optimal to remove manure with the calculated properties from the livestock house. In a cow barn with sawdust bedding introduced at the rate of 1 to $3 \mathrm{~kg}$ per head per day, with the manure channel $3400 \mathrm{~mm}$ wide, $200 \mathrm{~mm}$ deep and $75 \mathrm{~m}$ long, with the scraper height of $180 \mathrm{~mm}$ and the moving speed of $4.3 \mathrm{~m} \cdot \mathrm{min}^{-1}$, the unit ensured $98 \%$ - plus manure removal, specific energy requirement of manure transportation within $0.3-0.5 \mathrm{kWh} \cdot \mathrm{t}^{-1}$, and error-free life of at least 700 hours; the power consumption of one scraper ranged from 1.28 to $1.52 \mathrm{~kW}$.

\section{References}

[1] РД-АПК 1.10.15.02-17. Методические рекомендации по технологическому проектированию систем удаления и подготовки к использованию навоза и помета [Management Directive for Agro-Industrial Complex "Recommended Practice for Engineering Designing of Systems for Animal and Poultry Manure Removal and Pre-application Treatment]. Moscow: Rosinformagrotech Publ. 2017. 173 p. (In Russian). 
[2] РД-АПК 3.10.15.01-17. Методические рекомендации по проектированию систем удаления, обработки, обеззараживания, хранения и утилизации навоза и помета [Management Directive for Agro-Industrial Complex. Recommended Practice for Designing of Systems for Animal and Poultry Manure Removal, Treatment, Disinfection, Storage and Utilisation]. Moscow: Rosinformagrotekh, 2017. 160 p. (In Russian).

[3] РД-АПК 1.10.01.03-12. Методические рекомендации по технологическому проектированию ферм крупного рогатого скота крестьянских (фермерских) хозяйств [Management Directive for Agro-Industrial Complex "Recommended Practice for Engineering Designing of Pig Housing Facilities for Peasant (Private) Farms]. Moscow: Rosinformagrotekh Publ., 2013: 136 p. (In Russian).

[4] РД-АПК 1.10.01.01-18. Методические рекомендации по технологическому проектированию ферм и комплексов крупного рогатого скота [Management Directive for Agro-Industrial Complex "Recommended Practice for Engineering Designing of Cattle Farms and Complexes]. Moscow: Rosinformagrotekh Publ., 2018: 166 p. (In Russian).

[5] Kozlova N., Briukhanov A., Vasilev E., Shalavina E. Environmental assessment of livestock farms in Russia. Proc. Int. Sci. Conf. "Rural Development 2017. Bioecnomy challenges". Kaunas. 2017. pp. 330-336. DOI: http://doi.org/10.15544/RD.2017.189

[6] Luostarinen S., Grönroos J., Hellstedt M., Nousiainen J., Munther J.. Modeling Manure Quantity and Quality in Finland. Front. Sustain. Food Syst. 2018. 2. p. 60. doi: 10.3389/fsufs.2018.00060

[7] Шалавина Е.В., Брюханов А.Ю., Субботин И.А., Васильев Э.В., Козлова Н.П., Оглуздин А.С. Результаты расчетного и аналитического методов определения количественных и качественных характеристик навоза крупного рогатого скота [Results of estimated and analytical methods application for determining the quantitative and qualitative characteristics of cattle manure]. Technologies, machines and equipment for mechanised crop and livestock production: Технологии и технические средства механизированного производства продукции растениеводства и животноводства. 2018. No, 4 (97). pp.269-279. (In Russian).

[8] Damgaard-Poulsen H., Friis Kristensen V. (Eds.). Standard Values for Farm Manure. DIAS Report No. 7, Animal Husbandry, Ministry of Food, Agriculture and Fisheries Denmark, Tjele, 1998. pp. 1-107. [online][04.02.2019] Available at: http://www.scirp.org/reference/References Papers.aspx ?ReferenceID = 1594964

[9] Groenestein C.M., Valli L., Piñeiro Noguera C., Menzi H., Bonazzi G., Döhler H., Van der Hoek K., Aarnink A.J.A., Oenema O., Kozlova N., Kuczynski T., Klimont Z., Montalvo Bermejo G. Livestock housing. Options for Ammonia Mitigation: Guidance from the UNECE Task Force on Reactive Nitrogen. Edinburgh: Centre for Ecology and Hydrology. 2014. pp. 14-25.

[10] Keener H.M., Zhao L. A modified mass balance method for predicting NH3 emissions from manure $\mathrm{N}$ for livestock and storage facilities. Biosystems Engineering, 2008. Vol. 99, Issue 1. pp. 81-87.

[11] Kaasik S. Relationship between Livestock Nutrition and Excreted Nitrogen and Phosphorus Content. Ecosystem Health and Sustainable Agriculture. Christine Jakobsson (ed.) [online][04.02.2019] Available at: www.diva-portal.org/smash/get/diva2:602593/FULLTEXT02.

[12] Hristov A.N., Zaman S., Vander P.M., Ndegwa P.C., Larry S.S. Nitrogen losses from dairy manure estimated through nitrogen mass balance and chemical markers. Journal of Environmental Quality. 2009; Vol. 38, No. 6. pp. 2438-2448.

[13] Park K-H., Wagner-Riddle C., Gordon R.J. Comparing methane fluxes from stored liquid manure using micrometeorological mass balance and floating chamber methods. Agricultural and Forest Meteorology. 2010. Vol. 150, Issue 2. pp. 175-181.

[14]Ковалёв Н.Г., Гриднев П.И., Гриднева Т.Т. Научное обеспечение развития экологически безопасных систем утилизации навоза [Scientific support for the development of environmentally friendly manure disposal systems]. Agrarian Science of European North-East: Аграрная наука Евро-Северо-Востока. 2016. No. 1 (50). pp. 62-69. (In Russian). 